\title{
The Protection of the Gorilla (Gorilla Beringei Graueri) From Itombwe in the Democratic Republic of the Congo (DRC): A Case for Reconciling Environmental and Property Rights ${ }^{1}$
}

\author{
D.iur. Ambroise Katambu Bulambo \\ Catholic University of Congo, Kinshasa, DRC; University of Fribourg, Fribourg, Switzerland
}

\begin{abstract}
In 2006, the Congolese Minister of the Environment signed Decree No. 038/CAB/MIN/ECN-EF/2006 of 11 October 2006 establishing the "Réserve Naturelle d'Itombwe" (RNI)—Itombwe Natural Reserve — to safeguard a healthy environment conducive to the survival of eastern lowland gorillas (Gorilla beringei graueri) and other endemic species of the Albertine Rift. To achieve this goal, there is need to reconcile property rights and environmental law. Thus the harmonious fundamental right to ensure the protection of the dignity of the human being while guaranteeing in a harmonious way respect for nature itself would be guaranteed.
\end{abstract}

Keywords: land ownership rights of people-protection-environment-Gorilla-Itombwe

\section{Introduction}

In 2006, the Congolese Minister of the Environment signed Decree No. 038/CAB/MIN/ECN-EF/2006 of 11 October $2006^{2}$ establishing the "Réserve Naturelle d'Itombwe" (RNI) - Itombwe Natural Reserve. The purpose of this decision was to maintain a healthy and sustainable environment for the eastern lowland gorilla (Gorilla beringei graueri), the eastern chimpanzee (Pan troglodytes schweinfurthii) and, to a lesser extent, southern populations, forest elephants (Loxondonta africana cyclotis), and other endemic species of the Albertine Rift. Under Article 3 of this decree, it is now forbidden for anyone to use this forest or exploit it, in particular by introducing exotic species of animals and plants, firearms, traps, or any other hunting gear; to hold or transport live or dead wild animals, their hides or trophies, their meat, or any other fauna product; to pursue, hunt, capture, destroy, frighten, or disturb any animal species even animals deemed harmful to life; to do excavations, earthworks, etc. In addition, the management of the said reserve is entrusted exclusively to a State Body-the Congolese Institute for the Conservation of Nature-ICCN (Article 4 Decree No. 038/CAB/MIN/ECN-EF/2006).

\footnotetext{
D.iur. Ambroise Katambu Bulambo, Ph.D., professor of Law, Catholic University of Congo, Kinshasa, DRC; scientific associate, School of Law, University of Fribourg, Fribourg, Switzerland.

1 This article is taken from the interdisciplinary conference given at the UCC on April 7, 2017. Many thanks for Dr. Kinyalolo Kasangati Placide of translation in English.

2 038/CAB/MIN/ECN-EF/2006 Ministerial Order establishing a nature reserve called Itombwe Nature Reserve, "R.N.I.", J.O.RDC., 1 April 2007, No. 7, col. 73.
} 
This reserve of 760,000 ha is geographically located in the Congolese province of South Kivu, north-west of Lake Tanganyika (eastern DRC). ${ }^{3}$ This territory has been inhabited since time immemorial by persons belonging to the ethnic groups whose persons and territory constituted what became the Democratic Republic of the Congo on its independence (on June 30, 1960 (Article 10(3) Cst.). These include Bembe in the South, Lega in the West, Fuliru and Vira in the East, Shi and Nyindu in the North (Failly \& Bantu, 2010, pp. 2-3, 10). In Lega customary law, Bulega, their common territory, is divided into several clan territories (Bambula, Baliga, Bakano, Bashimwenda, Bakanga, Bashikasa, Bamulinda, Bamulinda, Bamenga, etc.). Bulega forms a co-ownership whereas the clan lands constitute an inalienable common property which confers on each member the solidary control over it, its use and usufruct. To dispose of this common property (to change its destination, to mortgage it beyond its indivisible nature, to alienate it) requires the unanimous consent of the other members of the clan or the lineage. Further, this consent must be announced by the highest ranking Mwami during a special assembly. The publicity was offered by this assembly (of the Bami and of all the members of the Clan) [serves/used to serve] as title deeds (in modern land registrer) and the authentic form of various contracts. To take possession and advantage of limited, actual rights to it (usus, fructus, usufructus ...), the owner must create a trail (kakala) and plant a special tree (e.g., ilongolongo, kikowa, ibila "palm tree", igoma "banana tree", or mulumba "ficus"). In case of non-compliance with this procedure, the right does not pass. In addition, when the exploitation of the land or forest causes the destruction of the environment (including water pollution, death of gorillas, large pangolins, lions, leopards, babies of animals), the criminal offense may be severely sanctioned (through muzombo or kintampo) by the Bami after a conflict resolution (mutendelo) (Bulambo, 2012, pp. 229-230).

For the local people, who consider themselves as the original owners of this land, the sustainable protection of the flora and fauna of Itombwe requires the cohabitation of people, fauna, and flora in accordance with ancestral customary law and under the protection of customary rule. For them, the right to a healthy environment conducive to its full development is a right for both people and fauna and flora. In addition, according to Article 34 Para. 3 Cst., "No one may be deprived of one's property except in the public interest and subject to a fair and prior compensation granted under the conditions fixed by law" (Art. 34 al. 4 Cst.).

For WWF and the Congolese State, the Itombwe forest is a property of the Congolese State (Article 7 Forest Code). It is the Congolese State that has the exclusive right to dispose of it and it is up to the Congolese State alone, and in application of the written law, to protect the fauna and flora of Itombwe. ${ }^{4}$ Faced with this legal conflict, it is up to the doctrine to think and propose solutions to different [sthg missing]. In this paper, the Swiss law applied to the creation of the INR as well as the customary local law will serve as sources of inspiration.

The paper is organized as follows. Section 2 introduces the protection of the environment in local customary law. Section 3 looks at the Swiss experience in the creation of the INR with respect to the right of ownership. Section 4 presents the correct interpretation of the decree creating the RNI with respect to the right of ownership in Congolese law. Section 5 concludes with some recommendations.

\footnotetext{
${ }^{3}$ WWF, Itombwe Nature Reserve (RNI), Gland, 2009, pp. 1-2.

${ }^{4}$ WWF, RNI, p. 2.
} 


\section{Protection of the Environment in Local Customary Law}

The Itombwe National Reserve is an ancestral property of several Congolese ethnic groups. The latter have enacted customary rules that protect the fauna and flora. They have also set up institutions to implement these customary rules. Among the Lega, for example, it is strictly forbidden to kill gorillas, pangolins, lions, leopards, and other special animals. It is also forbidden to burn the forest or to dump toxic substances in the water or rivers to indiscriminately and massively kill fish or to destroy the riverbeds. Lega customary law provides for severe penalties for violations of these customary rules. In the case of violation, it is the Bami who are judicial authorities as in other cases of violation of customary law. Penalties are often fines in kind and in cases of neglect [of palaver] or recidivism, the family of the offender may incur the wrath of the ancestors. This can be manifested in particular in the death of certain members of the family of the delinquent, in the loss of harvest (through hail, for example), through the development of infertility in women, or via many natural calamities. All members of the community believe in these consequences of non-compliance with customary Lega rules and respect this law. It is voluntary submission and without any penalty depriving people of liberty or any corporal punishment.

As can be seen, power and local customary law have protected the Itombwe fauna and forest since time immemorial. Hunting, fishing, agriculture, and forestry are regulated. The effectiveness of this right is obvious (Failly \& Bantu, 2010, pp. 3-4). For this reason, several international organizations support local civil society organizations to ensure that customs are respected by [customary law] and power (Failly \& Bantu, 2010, p. 4). In doing so, we have additional and complementary means of protection of the Congo River basin.

\section{The Creation of the Swiss National Park in the Respect of the Right of Ownership}

The Swiss National Park was created on August 1, 1914 by the Federal Council. This park is located in the canton of Graubünden and more precisely in the following five municipalities: Zernez (66.5\%), S-chanf (13.5\%), Scuol (13.2\%), Val Müstair (4.7\%), and Lavin (2.1\%). ${ }^{5}$ These municipalities are co-owners of the land on which the reserve extends. By creating this park in this co-ownership, the Confederation limited the property rights of these municipalities (Article 26 of the Federal Constitution). According to Art. 26 al. 1 Cst., the property right is guaranteed. In its individual function, the guarantee of ownership protects the owner's tangible economic rights: to preserve, to enjoy, and to dispose of his property. In the case of expropriation or restriction of property equivalent to expropriation, Art. 26 al. 2 Cst. poses the principle of full compensation, of which rent control measures, forced housing allocation, expropriation of the right of habitation to dispose of a property, of demolition or conversion of an immovable, limitation of the right to retain or dispose of any infringement of any of the prerogatives deriving from the right of ownership. ${ }^{6}$

Not being an absolute right, the right of ownership may be limited. To qualify, a restriction assumes that s. 36 Cst. fed. ${ }^{7}$ Art. 36 Cst. Fed. demands that any restriction on a fundamental freedom be based on a legal basis, justified by a public interest or the protection of a fundamental right of others, and proportionate to the aim pursued. ${ }^{8}$

\footnotetext{
5 These are percentages of the area occupied by the Swiss National Park.

${ }^{6}$ ATF 131 I 333, consid. 3.1.

7 ATF 141 I 20, consid. 4.

${ }^{8}$ ATF 131 I 333, consid. 43.1/ATF 141 I 20, consid. 6.
} 
In this case, the creation of the Swiss National Park is based on a sufficient legal basis (National Park Act, RS 454) and justified by a public interest, namely to allow the nature of all human interventions to be removed (Article 1 of the National Park Act). It remains only to analyze whether it is proportionate to the aim pursued, that is to say, if it is necessary to achieve the aims pursued by the Federal Council pursuant to Art. 1 of the National Park Act. In our case, the Confederation has given the responsibility for the National Park to a public law foundation headed by a National Park Commission which is its supreme body (Articles 2-5 of the National Park Act). This Commission ensures the maintenance and enhancement of the National Park ${ }^{9}$. In this sense, it collaborates with the canton and the municipalities; it administers, monitors, and maintains the park and its facilities; it informs the public about the nature and purpose of the National Park, as well as visitor requirements and it promotes collaboration between park administration and researchers (Section 5(1) National Park Act). This Commission is made up of nine representatives from the following organizations: Pro Natura-Swiss Nature Conservancy (three members), Swiss Confederation (two members), Swiss Academy of Sciences-Scnat (two members), Canton of Grison (one member), Co-owners of the land with a lease agreement (one member). In addition, the Swiss National Park has leased farm with the five co-owners (Zernez, S-chanf, Scuol, Val Müstair, and Lavin). Finally, these municipalities receive, from the Confederation, an annual fee for compensation in addition to the seat they occupy in the Board of Trustees. With these measures, it turns out that these municipalities have not lost their right of ownership and that the restriction to such ownership is proportionate to the intended purpose.

This pragmatic and century-old solution could serve as a model for the Congolese legislator to guarantee the harmonious fundamental right to ensure the protection of the dignity of the human being while guaranteeing in a harmonious way the respect for nature itself within the Natural Reserve of Itombwe.

\section{The Conformity of the Order Creating the Itombwe Natural Reserve With the Right of Ownership in Congolese Law}

On 11 October 2006, the Minister of the Environment issued a decision (Order No. 038/cab/MIN/ECN-EF/2006) establishing the Itombwe Natural Reserve (Articles 1-3) (Asimonyio Anio \& Kambale Katembo, 2015, pp. 1-4). This decision limits the rights of people who live in or around this forest. It is now necessary to consider whether these limitations are permissible with regard to customary property rights (Articles 153(4) and 34(2) of the Constitution).

According to Article 34 Para. 2 Cst., "The State guarantees the right to individual or collective property acquired in accordance with the law or custom". And no one may be deprived of his property except for reasons of public utility and subject to a fair and prior indemnity granted under the conditions fixed by law. This means that expropriation proceedings must be conducted and sanctioned by a decision taken by a competent judicial authority" (Article 34(4) and (5) of the Constitution). Finally, Article 14 CADHP guarantees ownership to any person, meaning the right of access to one's property that cannot be transported elsewhere; the right not to be deprived of property, the right not to have one's property or shelter (forest, house, village ...) destroyed or to be alienated; expropriate land or be deprived of the protection of its property, the use and control of its property.

\footnotetext{
${ }^{9}$ ATF 141 I 20, consid. 5.2.
} 
In view of the foregoing, the decree establishing the INR must, to be valid, be interpreted in accordance with the higher law (Article 34 of the Constitution and Article 14 of the CADHP) because it restricts the right of ownership of the people living inside and around the Itombwe Natural Reserve. This means that the restriction must be exercised in compliance with the requirements of Article 27 Para. 2 CADHP $^{10}$.

Indeed, according to Article 27 Para. 2 CADHP [end/footnote] for a restriction of rights and freedoms contained in the CADHP to be admissible, it must have a legal basis (Bulambo, 2013, pp. 123-124) ${ }^{11}$; that rights are exercised in respect of the rights of others, of collective security, of morality, and of the common interest; that the possible reasons for limitation are based on a legitimate public interest, i.e., this measure must pursue a legitimate aim; that the disadvantages of the limitation are strictly proportional and absolutely necessary for the advantages to be obtained; and that this limitation does not result in the fact of rendering the right itself illusory ${ }^{12}$, that is to say that this restriction must be necessary in a democratic society ${ }^{13}$. A restriction of the fundamental right pursues a legitimate aim when it is aimed at one of the objectives set out in the restricted fundamental right or where it is justified by one of the legitimate reasons for limitations of the rights and freedoms laid down in Article 27 Para. 2 CADHP, including respect for the rights of others, collective security, morals, and the common interest.

It must be necessary in a democratic society, which means that it must be a necessary means to achieve one or more of these goals or be the only way to avoid this disorder; it must be fit and adequate to achieve a legitimate objective or the disadvantages of the limitation must be strictly proportional and absolutely necessary for the benefits to be obtained. Lastly, this limitation must never result in "rendering the fundamental right in question illusory", that is, reconciling its exercise with other rights and freedoms with the safeguarding of certain interests. Considered essential, but this must not result in the annihilation or suppression of the rights in question. Applying this method to the guarantee of limited property rights by the Ministerial Decision creating the Itombwe Natural Reserve, it follows that:

1. The decision is based on a legal basis, the Forest Code $^{14}$ (Articles 7, 10-15). However, the classification of a forest is carried out after obtaining the assent of the provincial advisory council of the concerned forests, based on the prior consultation of the local population (Art. 15, first sentence, 1st sentence Forest Code). In this case, this opinion was not solicited (see the chapeau of the decree), including the communities that have occupied these lands since time immemorial and who own them according to custom (Article 10(3) of the Constitution). Moreover, in view of the restrictions on these populations, it is clear that the reserve created by the said ministerial decree is an integral nature reserve that does not allow cohabitation between man and nature.

\footnotetext{
${ }^{10}$ Com ADHP, Décision relative aux communications 140/94, 141/94 et 145/95, Constitutional Rights Projects et alii c. Nigeria, Para. 40-42/Com ADHP, Déclaration sur la liberté d'expression, Article II Para. 2/Com ADHP Décision relative aux communications 48/90, 89/93, 50/91 et 52/91, AI et alii c. Soudan, Para. 77-80.

${ }^{11}$ It is a material meaning of the law that is affirmed here. But when the restriction is serious, there must be a legal basis in the formal sense, a clear and precise law. For further information on the notion of legal basis, see Bulambo, A. K. (2013). The repression of Holocaust denial in Congolese law. Zurich: Editions Schulthess.

${ }^{12}$ Com ADHP, Décision relative à la communication 242/2001, Interights et alii c. Mauritanie, Para. 78/Com ADHP, Décision relative aux communications 105/93, 128/94, 130/94 et 152/96, Media Rights agenda and Constitutional Rights Project c. Nigeria, Para. 69 et 70 .

13 A. K. Bulambo, Négationnisme, pp. 50ss, 63ss, 122ss.

${ }^{14}$ Law No. 011/2002 of 29 August 2002 on the Forest Code in the Democratic Republic of Congo.
} 
According to Article 15 Para. 2, 2nd phr. Forest Code, the creation of such reserves (RNI) falls under the competence of the President of the Republic. In view of the foregoing, the existence of the legal basis for this decision becomes reasonably doubtful.

2. If the pursuit of a legitimate objective (the protection of endangered flora and fauna) is permissible, it remains to be analyzed whether this decision is appropriate and adequate to protect the fauna and flora at the expense of human beings or if this limitation makes the fundamental right of property of these persons illusory instead of reconciling the exercise of the right to a healthy environment and the right of ownership. By virtue of this decree, the local populations were expelled from their lands to make room for the protection (Failly \& Bantu, 2010, pp. 2-3) of fauna and flora ${ }^{15}$. These thousands of people are now internally displaced within the DRC and can no longer enjoy their ancestral lands. The Bakanga clan of the Lega, for example, has been totally expelled from Kikindi, their ancestral lands, and they are now refugees in Mwenga, Kamituga, or Kabilongo. In addition, the Lega can no longer organize initiatory schools (lutende) and transmit knowledge and skills. They cannot even enter, or pay homage to, the burial grounds of their ancestors. It is indeed a disproportionate measure that renders the property rights of local populations illusory or expropriation in total disregard of constitutional law (Articles $34 \mathrm{Cst}$. and 14 ACHPR). And yet, there are alternative solutions that are less restrictive of property rights and respectful of environmental law. These solutions come from local cultural law and Swiss law. For example, it was necessary to create the national reserve while allowing local populations to continue to live within these reserves in accordance with customary law and written law. Customary law, for example, contains strict rules for the protection of the forest (suppression of fires and denaturing of water) or wildlife (protection of several species, reproduction of all species, regulation of hunting). Respect for this dualistic right should be guaranteed by state judges (Article 153(4) of the Constitution) and customary judges recognized by Article 207 of the Constitution. The complementarity of these authorities is a better protection of the environment in a bankrupt state like the DRC where state justice and administration are in a very advanced state of dysfunction. Accompanying measures should also be taken. To prevent illegitimate customary power from becoming itself predatory, civil society (including local churches) and clan mutuals should be involved in the management of the said reserve. Development projects should be financially supported by the international community (Article 5 of Order No. 038/cab/MIN/ECN-EF/2006 of 11 October 2006 establishing the Itombwe Nature Reserve, Failly \& Bantu, 2010, pp. $\left.11-16^{16}\right)$. Thus, it would contribute to achieving the object of the Paris Agreement as defined in Articles 2 and 9 (UN, 2015, §53). These solutions would also make it possible to realize other fundamental rights guaranteed by the Congolese Constitution. The latter guarantee every person the right to a healthy environment conducive to their full development (Article 53(1) of the Constitution); their right to enjoy national wealth (Article 58 of the Constitution and Articles 36-44 of the Forest Code) and their right to enjoy the common heritage of humanity (Article 59 of the Constitution). WWF and the Congolese State have the obligation to respect these human rights and fundamental freedoms enshrined in the Constitution (Article 60 of the Constitution). Finally, the Swiss experience built during the century of existence of the national park (see Section 3) can serve as a source of

\footnotetext{
15 Already in 1975, people who used to live in the Kahuzi-Biega National Park (also a gorilla park) in the province of South Kivu, whose area had just been increased tenfold to 600,000 ha, had been expelled manu militari.

${ }^{16}$ From the same opinion: Art. 5 of the decree 038/cab/MIN/ECN-EF/2006 of 11 October 2006 creating the Itombwe Nature Reserve.
} 
inspiration for the DRC in reconciling the land ownership rights of people belonging to the ethnic groups living in the National Park of Itombwe and the protection of the environment.

\section{Conclusions}

The following can be retained from this article:

1. The Congolese constituent consecrates the right of individual or collective property acquired in accordance with the law or custom (Article 34(2) of the Constitution) and recognizes to everyone the right to a healthy environment conducive to its full development and the duty to defend him (Article 53(c)).

2. The constituent obliges the State to ensure the protection of the environment and the health of the population and imposes on it the respect for human rights and fundamental freedoms enshrined in the Constitution. Indeed, all human rights are equal and interdependent (Hertig Randall, 2014, pp. 51-52).

3. The Congolese constituent recognizes the customary authority established by custom (Article 207 of the Constitution) and custom as a legal basis on which the State may base its decision (Article 153(4) of the Constitution). Recognition or not of land ownership of a person or a clan or an ethnic group (Article 34(2) of the Constitution).

4. Constituent also acknowledges that "No one may be deprived of his property except in the public interest and with a fair and prior compensation granted under the conditions set by law and Nobody can be seized in his property that under a decision taken by a competent judicial authority" (Article 34(3) and (4) of the Constitution). In the creation of the Itombwe Reserve, there is no judicial decision that has established its public utility and set a fair and prior indemnity for the owners of the said forest transformed into a reserve by order of the Minister of the Environment.

5. The constituent imposes on the legislator to lay down in a law fundamental principle concerning the protection of the environment (Article $123 \mathrm{Cst}$.). To achieve this, the law must be inculturated and pragmatic, in particular to protect gorillas (Gorilla beringei graueri) of the Itombwe Nature Reserve in the DRC - an integral part of the Congolese river basin - in parallel with the women and men who live there. This will be achieved, in particular, by adopting a new long-term strategy for the conservation and sustainable management of forests (Article 4 Paris Agreement). This strategy would include:

- The reconciliation of property rights and environmental law, which requires the cohabitation between gorillas and men, as in the past, in accordance with modern written law and customary environmental law (Articles 153(4) and 34(2) of the Constitution) on the one hand, and the inclusion of customary institutions in the application of the law (Articles 207 and 153(4) of the Constitution). Customary law has a pragmatic and effective solution. It allows people belonging to the Congolese ethnic groups to retain ownership of the forests that make up the reserve and protect the fauna and flora that exists while allowing their rational and sustainable exploitation. For example, hunting and fishing for certain species of animals and fish is allowed. The same goes for picking mushrooms, fruits, or phytosanitary products.

- Compensation of the owners of the Itombwe Nature Reserve for enduring deprivations (prohibition to visit the tombs of their ancestors or to organize initiatory rites, prohibition of hunting, fishing, or mushroom picking, fruits or plant protection products, etc.) since 2006.

- The creation of the Itombwe Nature Reserve in accordance with the law (Article 15 Forest Code and Articles 34(4) and 5 (Cst.)). 
- The granting of fair and equitable compensation for the future deprivation of certain attributes (abusus and usus) of collective property due to the creation of the Itombwe Nature Reserve (Article 34(4) of the Constitution). One example would be the creation of the Reserve together with the periodic authorization for persons belonging to the ethnic groups/clans who own the forest on which the Reserve is erected to retain the ownership of the forests constituting the reserve, to contribute to its protection while periodically authorizing the hunting of certain species of animals, the fishing of certain species of fish, agriculture as well as the picking of mushrooms, fruits, or phytosanitary products. In addition, the Congolese State (lessee) should pay these landowners periodic rent (annual or semi-annual). ${ }^{17}$ Finally, access to the Reserve should be guaranteed to local populations to visit the tombs of their ancestors or to organize initiation rites. Thus "the harmonious fundamental right to ensure the protection of the dignity of the human being while guaranteeing in a harmonious way respect for nature itself" (Fluckiger, 2014, pp. 606, 617-619) would be guaranteed within the Itombwe Nature Reserve in accordance with the land and environmental property rights of indigenous peoples. It is there, "Put in place mechanisms for sustainable, integrated and comprehensive management based on a national land policy in line with the socio-economic dynamics and international commitments of the DRC" and establish a harmonized legal framework and integrated and clearly and effectively recognize the native land rights of indigenous peoples living in the Itombwe National Reserve (Republique Democratique du Congo, 2013, pp. 3-5, 36-37).

\section{References}

Asimonyio Anio, J., \& Kambale Katembo, B. (2015). Rapport de la mission de la zone 07 dans la réserve naturelle d'Itombwe. Sud-Kivu, RD CONGO. Kisangani: Centre de surveillance de la Biodiversité (CSB)/Université de Kisangani.

Bulambo, A. K. (2012). La RD Congo. Les TICS dans l'apprentissage des Droits de l'homme. Saarbrück: Editions universitaires européennes.

Bulambo, A. K. (2013). The repression of Holocaust denial in Congolese law. Zurich: Editions Schulthess.

Failly, D., \& Bantu, J.-M. (2010). La forêt d'Itombwe: Enjeux socio-économiques et conservation de la nature en contexte congolais. Bukavu: Terre citoyenne et association des populations des montagnes du Monde.

Fluckiger, A. (2014). Droits de l'homme et environnement. In M. Hertig Randall and M. Hottelier (Eds.), Introduction aux droits de l'homme. Zurich: Editions Schulthess.

Hertig Randall, M. (2014). Typologie des droits de l'homme. In M. Hertig Randall and M. Hottelier (Eds.), Introduction aux droits de l'homme. Zurich: Editions Schulthess.

Republique Democratique du Congo. (2013). Réforme foncière. Kinshasa: Ministère des affaires foncières.

UN. (2015). Framework convention FCCC/CP/2015/L.9 of 12 December 2015 on climate change. Conference of the Parties, twenty-first session held in Paris, 30 November-11 December 2015.

\footnotetext{
17 The payment of this rent would be inspired by the centenary Swiss law applied during the creation of the Swiss National Park. In doing so, the authorities Helvetians reconciled the property rights of the communes with the property on which the park was erected and committed themselves as tenants to pay rent to the owners.
} 